\title{
A Philosophical Analysis of the Effectiveness of Legislation in Upholding Sexual Purity among Teachers in Kenya
}

\author{
Edward Maina Andafu \\ Lecturer in Philosophy of Education \\ Kenyatta University \\ Atieno Kili K'Odhiambo, PhD \\ Senior Lecturer in Philosophy of Education \\ University of Nairobi \\ Samson Okuro Gunga, PhD \\ Professor of Philosophy of Education \\ University of Nairobi \\ Kenya
}

\begin{abstract}
This paper undertakes a philosophical analysis of the effectiveness of legislation in upholding sexual purity among teachers in Kenya. The Government of Kenya and the Teachers Service Commission (TSC) have enacted legislation to govern teachers' sexual conduct. However, analysis of the incidences of teachers' sexual abuse of their learners reveal that legislation merely creates awareness among teachers on the need to refrain from committing sexual offences. It does not stimulate their mind to think critically and make informed judgment concerning sexual purity. The study proposes incorporation of moral education in the Teacher Education curriculum, facilitated by the dialectical method of teaching which activates critical thinking and ultimate formulation of reasoned judgment.
\end{abstract}

Keywords: Critical thinking, Dialectical Method, Learner, Legislation, reasoned judgment, Sexual abuse, Sexual purity, Teacher

\section{Introduction}

Teachers play a pivotal role in the process of facilitating dissemination of knowledge, skills and attitudes that are deemed necessary for the learners' as well as the country's development. Teaching is a noble profession that demands sacrifice and self-denial, hence teachers are entrusted with the responsibility to mentor the learners into morally upright individuals through academic empowerment and moral development. As second parents, teachers are expected to protect, love and care for the welfare of their learners, as expressed in various pieces of established legislation. To the contrary, some teachers sexually abuse their own learners with whom they are entrusted to protect and nurture. Teachers' indulgence in the vice betrays the nobility of the teaching profession, besides destroying the lives of the victims. Occurrence of such incidents cast doubt on the effectiveness of legislation in upholding teachers' sexual purity. This paper analyses the effectiveness of legislation in maintaining sexual purity among teachers. The paper is divided into four sections. Section one provides the background to the concept of sexual abuse, while the second section examines the pieces of legislation enacted to protect children against sexual abuse. Section three examines incidences of teachers' sexual abuse of their learners, whereas the fourth section analyses the main themes of the paper and proposes a moral education program, facilitated by the dialectical method of teaching.

\section{Background to the concept of sexual abuse}

Sexual offence is a general term that refers to deliberate and unlawful sexual acts aimed at either stimulating sexual excitement or obtaining sexual gratification by the offender. Such acts include rape, sexual violence, sexual abuse, defilement, prostitution and possession of pornographic material among others (Government of Kenya, 2006). The United Nations International Children's Emergency Fund (UNICEF) considers sexual violence to be an umbrella term that constitutes all types of sexual victimization. Sexual violence among children encompasses cases in which a child is compelled to perform a sexual act by a caregiver, coerced to indulge in sexual intercourse or being forced to expose their sexual body parts UNICEF, 2014). The most common form of sexual offence directed to school children is sexual abuse. 
Child sexual abuse refers to any physical, visual or verbal behavior by an adult directed at a child, which is aimed at sexually arousing them (Magwa, 2014). This paper takes sexual abuse to include sexual offences directed towards the learners by their teachers. Sexual abuse can be grouped into two categories, namely contact and non-contact. Bezuidenhout (2008) and Richter et al. (2004) concur that non-contact sexual abuse occur without the actual sexual contact between the abuser and the victim. This involves exposure to pornography, sexting, verbal sexual harassment such as innuendos and request for sexual favors (Heighberg, 2005). Non-contact sexual abuse communicates sexual messages and when directed at children they are a prelude to sexual abuse. Contact sexual abuse constitutes sexual contact activities such as caressing, fondling or tickling one's genitals, breasts or thighs; oral sexual activities such as sucking of breast, tongue kissing and penetrative sexual activities which include oral, anal and vaginal intercourse (Gandari and Chihambakwe, 2010). Some school children experience both the non-contact and contact sexual abuse perpetuated by the very teachers who are required to protect and care for them. Therefore, the government has enacted pieces of legislation to protect children from all forms of sexual offences.

\section{Established legislation to protect children against sexual abuse}

Sexual abuse against school children infringes on their fundamental human rights as enshrined in Chapter Four of the constitution of the Republic of Kenya. The constitution identifies the inherent dignity of the human person which has to be respected and protected. It states that no person should be subjected to any form of violence or treated in a cruel, inhuman or degrading manner (Republic of Kenya, 2010). Any form of sexual act directed to a learner therefore violates sections of Chapter Four of the Constitution of Kenya. The Public officer Ethics Act CAP 183 of 2003 on the other hand, is an Act of Parliament that governs the ethical conduct of public officers. Being registered employees of a constitutional commission; the Teachers Service Commission (TSC), teachers are considered to be public officers, thus this Act equally applies to them. Among the forms of ethical conduct stipulated in the said Act include prohibition from indulgence in sexual offences by public officers. These include but not limited to sexual harassment (Republic of Kenya, 2003). The Public Officer Ethics Act CAP 183 in turn mandates the Teachers Service Commission to formulate the Code of Conduct ad Ethics for teachers.

Following numerous cases of violation of children's rights, the Government of Kenya enacted The Children's Act CAP 141 in 2001 in order to provide for not only parental responsibility, but also care and protection of the welfare and rights of children. The Act provides for the care and protection of children from sexual exploitation, coercion to indulge in sexual activity as well as exposure to obscene material (Republic of Kenya, 2001). This Act requires the caregivers to provide all the necessary support and protection to the children against violation of their human rights. The Government of Kenya (2006) enacted the sexual offences Act No.3, specifically to prevent and protect all persons from unlawful sexual acts. It encompasses various forms of sexual offences and prescribes punitive penalties in case of breach (Government of Kenya, 2006). The Act prohibits sexual offences committed against children, who are the future generation of the country. Violation of the said Acts attracts hefty court fines and long jail terms. All the citizen of Kenya are required to acquaint themselves with all these legislation and subsequently comply with them. In addition to the mentioned pieces of legislation that apply to all citizens of Kenya, the Teachers Service Commission (TSC)Act No.20 of 2012 mandates the Teachers Service Commission to formulate the Code of Regulations governing the conduct of teachers. The Act outlines offences and disciplinary procedures undertaken in the event that teachers violate the Act. The offences include but not limited to sexual offences (Republic of Kenya, 2012). The TSC Code of Regulations comprises offences for which teachers may be taken to account and the disciplinary measures to be meted in case of breach. The Teachers Code of Regulations highly prohibits sexual immorality among teachers such that those who are found guilty of sexually abusing their learners are dismissed and subsequently deregistered (Government of Kenya, 2014b).

The Public Officer Ethics Act CAP 183 of 2003 mandates the Teachers Service Commission to establish the teachers Code of Conduct and Ethics. The Code contains rules of conduct and ethics to be observed by teachers so as to maintain the integrity and nobility of the teaching profession. Among other rules, the Code equally prohibits sexual relations between teachers and learners, regardless of whether the latter consent or not, and that teachers who are found culpable are dismissed and deregistered. Once a teacher is deregistered, they cannot offer teaching services in any school because their professional certificates get confiscated by the Teachers Service Commission. Teachers are expected to uphold high moral and ethical standards so as to be emulated by their learners and the public at large. In order to achieve this, they are obliged to read and comply with the aforementioned pieces of legislation.

\section{Teachers 'violation of the established legislation}

Despite the established rules meant to promote sexual purity among teachers, there are a number of reported cases of teachers who sexually abuse their learners. Teachers' indulgence in sexual abuse is not a new phenomenon in Kenya, it 
has persisted for some years. Following the rampant incidents of sexual abuse of learners by teachers, TSC issued Circular No. 3/2010 regarding the protection of learners from sexual abuse. The circular identifies sexual abuse of school children as a violation of their human rights hence it is highly prohibited. Teachers are therefore required to protect their learners from the vice (TSC, 2010). Kiruki (2014) observes that an upsurge in the number of student defilement by teachers raises questions on the ability of the TSC's stringent rules to curb the vice.

In a shocking revelation, a primary school teacher in Murang'a County was sentenced to 90 years in jail after being found guilty of sexually abusing 10 pupils by fondling and kissing them (Mwaura, 2016). Statistics from TSC indicate that out of the 126 teachers who were deregistered between the year 2011 and 2015, 100 of them had been found guilty of sexual abuse. Between June and July 2016, other 22 teachers were dismissed and subsequently deregistered due to sexual misconduct (TSC, 2016). In the TSC's opinion, dismissal of the offenders would deter other teachers from indulging in a similar behavior. However, two years later, TSC deregistered 29 teachers after they were found guilty of having sexual affairs with their learners (TSC, 2019). Appearing before the Senate Committee on Education, TSC Chief Executive Officer disclosed that in the preceding eight years, a total of 1,077 teachers had been dismissed from the service due to sexual misconduct (Wanzala, 2019).

Most of the perpetrators of sexual abuse exploit the plight of some learners, especially orphans raised by their grandparents. They take advantage of their vulnerable socio-economic background to lure them into having sexual affairs with them. As explained by the South African Council for Education (SACE), many cases go unreported because the perpetrators bribe and silence the victims and their kin. They also use financial incentives to persuade the victims to drop the charges or deny the allegations against the perpetrators. In some cases, third parties are used to persuade the victims' kin to accept financial offers as settlement for their sexual misconduct (SACE, 2017). Fatuma and Chege (1995) observe that some teachers buy sex from the students by giving them money or gifts, examination leakages among other incentives. Due to such incentives, the victims get dissuaded from reporting the cases. The cited incidents of teachers' sexual abuse of their learners reveal that the vice is still rampant despite the legislation put in place to curb it.

\section{Analysis}

Sexual abuse in schools is a highly destructive form of child abuse manifested in verbal, psychological harassment, sexual assault among others. Experiences of sexual abuse hinder all aspects of a child's development: physical, psychological and social. Besides the physical injuries that accrue, exposure of the victim to HIV and other sexually transmitted infections is possible. As noted by Fatuma and Chege (1995), girls who are sexually abused can hardly concentrate in class and some drop out due to pregnancy. Poor academic performance is common amongst sexually abused children (Bromberg and Johnson, 2001). However, some sexually abused learners become academic achievers because they direct their energy to school work as a coping and compensatory mechanism (Magwa, 2014). Sexual abuse of school children by their teachers not only compromises their academic standards, but also degrades them as human beings, threatening their health and even endangering their lives (Adhami et al., 2017). Research findings reveal that sexual abuse of school children can lead to a wide range of mental health consequences including depression, withdrawal, panic disorders and anxiety, which can sometimes be manifested in suicidal tendencies. Such psychological consequences can be severe due to the stigma that accompanies the act. Some learners can also begin engaging in risky sex, drug and alcohol abuse.

Victims of sexual abuse may also develop insecure social attachments to others and face difficulty in building and sustaining relationships in their future lives. They may develop fear or entrenched negative perception and threat from members of the opposite sex. Such children find it difficult to establish interpersonal relationships. They become socially withdrawn and do not freely mingle with their peers (Hall and Hall, 2011). It is evident that the effects of sexual abuse are undoubtedly so adverse that they spoil the learners' future life by interfering with their academic, psychological and social development. Ultimately, the overall purpose of education cannot be achieved. TSC has established rules, issued circulars and acted on cases reported to them. Despite all the legislation and circulars, acts of sexual abuse of learners by their teachers are on the rise. What is not working? Are they the circulars, the punishment or the laws? Persistent cases of teachers' abuse of their learners attests to the ineffectiveness of legislation and punishment in upholding sexual purity among them. Sexual purity is a deeply embedded value system that cannot only be instilled by the use of legal mechanisms or punishing of offenders. It requires transformation of an individual's mindset, values and attitudes. Legislation only serves to create awareness and deter teachers from sexual misconduct, whereas punishment only weakens and temporarily suppresses undesired behavior. Punishment does not teach any new desired behavior, and given favorable conditions the suppressed behavior can still recur. 
The perpetrators can as well devise alternative mechanisms of perpetuating the vice. Recurrent incidents of teachers' sexual abuse of their learners attest to this. Sexual purity is a fundamental component of morality that teachers are supposed to uphold, by virtue of the nobility and sacrificial nature of their profession.

The most appropriate way to instill sexual purity among teachers is through education. Unfortunately, Teacher Education programs in Kenya focus on perfecting the teachers' instructional competence at the expense of integrity (Kafu, 2011). A survey conducted by the Kenya Institute of Curriculum Development (KICD) reveals that both student teachers and their educators consider integrity as an emerging and a pertinent issue that requires incorporation in the Teacher Education curriculum (KICD, 2016). Lack of integrity course in the Teacher Education curriculum culminates in the training of teachers who do not fully understand their role in the profession, other than instructional competence. Subsequently, some of them indulge in acts that contravene the dictates of the teaching profession.

Although some teachers literary violate the established legislation by indulging in sexual misconduct, not all of them are conversant with the laid out legislation (Langat, 2015). This justifies the need for a moral education program for the teachers. However, it is noteworthy that teachers' mere awareness of the rules governing sexual conduct cannot translate to maintenance of their sexual purity. Some of them are aware of expectations of their ethical conduct but usually succumb to the influence of sexual lust. This implies that they possesses superficial knowledge of their professional integrity that is easily swayed by their bodily emotions. When teaching virtue, two states of the human mind should be put into consideration. These are doxa and episteme. The former domain entails opinion or belief, whereas the latter is the real knowledge. Common belief or opinion is based on hearsay, for instance by reading from the book or by being told by someone. When teachers read about the rules prohibiting sexual abuse of school children, they do not develop concrete behavior that can propel them to uphold sexual purity. Legislation merely creates awareness at the expense of developing moral virtues. On the other hand episteme, as Aristotle puts it, entails not only knowing 'that,' but also 'why.' It is the ultimate knowledge that one attains and internalizes as a result of critical thinking and application of reason. Such knowledge is real and it is entrenched in the human psyche. Therefore it is possible to ascend from the mental state of doxa, to episteme by use of the dialectical method of teaching and learning. The term dialectical is Greek in origin, derived from the term dialegein, 'to argue' or 'converse' for the purpose of reaching a conclusion (Audi, 1991). Being a conversation, the dialectical method of teaching involves a teacher's crossexamination of the learner so as to delve into the latter's deeper knowledge about a given concept. Such engagement among the interlocutors helps to stimulate critical thinking and draw out concrete ideas and judgment mediated by reason. The method constitutes a co-operative argument between the interlocutors, aimed at drawing out ideas and underlying presuppositions. In the process, the learner understands and internalizes the underlying meaning of the concept, thereby bringing forth new ideas and arriving at informed decisions. This method is characteristic of Socrates, hence referred to as the Socratic Method. In the Plato's Meno, Socrates demonstrates what the Dialectical Method can yield. He cross-examines a slave boy (who has not studied Geometry before) until he (boy) arrives at the correct answer of a geometrical equation. Rigorous dialectical encounter therefore activates the mind to think critically until a person makes a reasoned judgment. Sexual lust is an emotional desire that cannot be managed just by creating awareness. It requires facilitation of a rational discourse which makes the teachers to open up, apply reason and come up with their own informed decision to uphold sexual purity. When applied in the teaching of professional integrity, the dialectical method would make teachers think critically about the ethical obligation of their profession in relation to the overall purpose of education, and their central role in the holistic development of the learner.

Granted the dual nature of the human beings, as contended by Plato in his dialogue, Phaedo (translated by Grube, 2002), teaching of virtue should therefore transcend the corporeal domain of the human person. The human person consists of the body and the soul. The soul is the incorpreal essence of the humankind while the body is the corporeal being. Human actions stem from the soul, while the mind dictates the body on the way to act. Therefore all the human overt actions are a manifest of their soul as expressed by the mind. In order for teachers to transcend to the mental state of real knowledge (episteme), they need to undergo a rigorous dialectical discourse that will arouse their faculty of reason so that they act in consonant with their reasoned direction. Moral behavior that results from such a rational discourse is concrete since it emanates from the human subconscious. In order to perfect sexual purity among teachers, the teaching of moral education should then take a dialectical approach that guarantees development of a concrete behavior that cannot succumb to bodily emotions.

\section{Conclusion}

As observed in the foregone discussion, enactment of legislation and subsequent execution of punishment to the perpetrators of sexual abuse does not guarantee maintenance of sexual purity among teachers. Instead they promote superficial learning and temporary suppression of unwanted behavior. 
Sexual purity is a value system embedded in the incorpreal domain of the humankind. It can only be attained through the dialectical approach of teaching that strikes the human psyche so as to activate critical thinking that would facilitate formulation of reasoned judgment.

\section{References}

Audi, R. (1991). The Cambridge Dictionary of Philosophy. ( $2^{\text {nd }}$ ed.). New York: Cambridge University Press.

Adhami, S., Chenelle, N., Freeman, M., \& Gaulino, M. (2017). Girl's education under attack: The detrimental impact of sexual abuse by teachers on school girls' human rights in Kenya. A human Rights Report and Proposed Legislation. Georgetown, University Law Center.

Bezuidenhout, F. J. (2008). Child sexual abuse: A reader on selected social issues. Pretoria: Van Schaik Publishers.

Bromberg, D.S., \& Johnson, B. T. (2001). Psychology in schools. London: John Wiley \& Sons, Inc.

Fatuma, N., \& Chege, D. (1995). Sexual harassment in unaided Harambee Schools. Nairobi: The Free Press.

Gandari, E., \& Chihambakwe, W. (2010). Crisis counselling. Harare, Zimbabwe Open University.

Hall, M., \& Hall, J. (2011). The long-term effects of childhood sexual abuse: Counselling implication. Retrieved 19, April, 2019 from http://counsellingoutfitters.com

Heiberg, T. (2005). Essential learning points: Listen and speak out against sexual abuse of girls and boys. Save the children. Retrieved 19, April, 2019 from http://www.reddbarna.no/default.asp? V-ITEM-ID=2210

Kafu, P. A. (2011). Teacher Education in Kenya: Emerging issues. International Journal of Curriculum and Instruction. Vol. 1. (1) pp. 43-52.

Kariuki, T. (2014, November 2). Teacher's panel taken to task by court over increase in defilement. Sunday Nation Newspaper, p.34.

KICD. (2016). Research Report and draft framework for teacher education in Kenya. Unpublished Research Report, Nairobi.

Langat, K. (2015). Evaluation of Teachers Service Commission Code of Conduct and Ethics in preventing secondary school teacher-student sexual relations in Bomet County, Kenya. A Master of Education Research Project of Maasai Mara University.

Magwa, S. (2014). Managing sexual abuse of students by teachers. A case study of Masvingo District Secondary Schools in Zimbabwe. International Journal of Education Learning and Development, Vol. 2, No. 2, pp. 1121.

Mwaura, M. (2016, June 2017). It's 90 years in jail for teacher who defiled boys. Daily Nation Newspaper, p.12.

Plato. (2002). Five dialogues: Apology, Crito, Euthyphro, Meno and Phaedo (2 ${ }^{\text {nd }}$ ed.). (G. M. A. Grube, Trans.). Indianapolis: Hackett Publishing Company.

Republic of Kenya. (2001). The Children Act CAP 141. Nairobi: National Council for Law Reporting.

Republic of Kenya. (2003). The Public Officer Ethics Act CAP 183. Nairobi: The National Council for Law Reporting.

Republic of Kenya. (2006). The Sexual Offences Act No.3.Nairobi: National Council for Law Reporting.

Republic of Kenya. (2010). The Constitution of Kenya. Nairobi: The National Council for Law Reporting.

Republic of Kenya. (2012). Teachers Service Commission Act No.20. Nairobi: The National Council for Law Reporting.

Republic of Kenya. (2014a). Teachers Service Commission Code of Conduct and Ethics. Nairobi: Government Printer. Republic of Kenya. (2014b). Teachers Service Commission Code of Regulations. Nairobi: Government Printer.

Richer. L., Dawes, A., \& Higson-Smith, C. (2004). The many kinds of sexual abuse of young children.

Cape Town: HSRC Press

SACE. (2017). Factors facilitating sexual related misdemeanor between teachers and learners.

Retrieved 17, April, 2019 fromhttps://www.sace.org.za/assets/documents/uploads/sace-79756-12-06-FACTORSFACILITATING SEXUAL-RELATED MISDEMEANOUR BETWEEN TEACHERS AND LEARNERSCPTD.pdf

TSC. (2010, April 29). Circular No. 3/2010 on protection of pupils and students from sexual abuse. Nairobi.

TSC. (2016). Circular No. 10/2016 on deregistered teachers. Retrieved 17, April, 2019 from

https://www.tsc.go.ke/index.php/media-centre/downloads/category/18-gazette notices

TSC. (2019). Deregistered teachers. Retrieved 17, April, 2019 from https://www.tsc.go.ke/index.php/mediacentre/downloads/85-de-registered-teachers

UNICEF. (2014). Hidden in plain sight. A statistical analysis of violence against children. New York.

Wanzala, O. (2019, March 13). TSC: 1,077 teachers sacked for sexually harassing students.

Retrieved 18, April, 2019 from https://www.nation.co.ke/news/education/Teachers-sacked-love-affairs/26436045023270-nlaw6a/index.html 